\title{
Follow-up of multibacillary leprosy patients using a phenolic glycolipid-I-based ELISA. Do increasing ELISA-values after discontinuation of treatment indicate relapse?
}

\author{
R A M CHIN-A-LIEN, * W R FABER, $\dagger$ M M VAN RENS, \\ D L LEIKER, $\dagger$ B NAAFS* \& P R KLATSER $\ddagger$ \\ *Department of Dermato-Venereology, Dijkzigt Hospital, Erasmus \\ University Rotterdam, Dr. Molewaterplein 40, 3015 GD Rotterdam, \\ The Netherlands; $\dagger \dagger$ Department of Dermato-Venereology, Academic \\ Medical Centre, University of Amsterdam, Meibergdreef 9, 1105 \\ AZ Amsterdam, The Netherlands; $₫ N$.H. Swellengrebel Laboratory \\ of Tropical Hygiene, Royal Tropical Institute, Meibergdreef 39, \\ 1105 AZ Amsterdam, The Netherlands
}

\begin{abstract}
Accepted for publication 22 July 1991
Summary With the introduction of reproducible serological tests it was hoped that relapses in leprosy patients, after discontinuing treatment, could be detected before damaging reactions occurred and before the patients became infectious. The possible value of an ELISA using a semisynthetic analogue of phenolic glycolipid-I to detect antibodies to this antigen in order to predict a relapse in multibacillary patients was investigated. In contrast to that reported for paucibacillary patients, this test was useful to detect early relapses in multibacillary patients. In 3 out of 4 multibacillary patients who relapsed, the ELISA-values were increased. The decreased ELISA-values in the one relapsed patient could be attributed to the corticosteroid therapy. In the multibacillary patients who did not relapse after RFT, the ELISA-values were consistently low or decreased. In only one patient did the ELISA-values increase following his release from treatment and this patient was clinically suspected of developing a relapse.
\end{abstract}

\section{Introduction}

Until recently, lepromatous leprosy patients were treated for a minimum of 10 years, but frequently longer.' After they were released from treatment (RFT), a certain number relapsed. $^{2}$

With the introduction of multiple drug treatment (MDT), as advised by the WHO, it was expected that the treatment period could be shortened to 2 years. However, some leprologists advised treatment to continue after this period until a negative bacterial index (BI) was achieved. ${ }^{3}$ There was concern, however, that despite the highly effective 
treatment relapses would still occur due to persisting bacilli. After RFT, regular followup, involving clinical assessments and skin smears, was therefore recommended. ${ }^{4}$ When serological tests (Radio Immuno-Assay and ELISA) became available and were shown to be reproducible and reliable, it was hoped that these tests could be used to detect an early relapse, ${ }^{5}$. However, it was observed that the native phenolic glycolipid-I(PGL-I)-ELISA test was not sensitive enough to detect relapses in paucibacillary leprosy patients. ${ }^{6}$ The test proved to be sensitive for the follow-up of individual multibacillary leprosy patients. ${ }^{7}$

Until recently, large numbers of multibacillary patients world-wide were allowed to discontinue the treatment, their follow-up is crucial. Early detection of relapse could help in timely therapy before any irreversible damage occurs. In this paper, the results and the value of a PGL-I based ELISA for the follow-up of multibacillary leprosy patients after RFT in the Netherlands are reported.

\section{Materials and methods}

\section{MATERIALS}

Combined therapy including daily rifampicin was introduced in the Netherlands in $1979 .{ }^{8}$ The WHO-advised MDT regimen with once monthly rifampicin was implemented in 1986. Sera from patients who were RFT from 1982 onwards were stored. Sera were also obtained and stored at $-20^{\circ} \mathrm{C}$ from the 568 patients still attending leprosy clinics in Amsterdam and Rotterdam. At present only 16 of those patients who had received combined therapy have relapsed. From the multibacillary leprosy patients who had relapsed, sera were available from 4 patients before and after RFT. The sera of these 4 patients were analysed with the phenolic glycolipid-I ELISA test using a synthetic neoglycoprotein ('Gigg Disach' obtained via WHO) as described by Brett et al. ${ }^{9}$ The results of the test are given in optical density (OD). Values higher than $\mathrm{OD}=0 \cdot 150$ are considered to be positive. ${ }^{10}$

\section{History of the 4 patients}

Patient 1 had suffered from lepromatous leprosy since 1956. He came to the Netherlands in 1977 from Suriname. He had been treated with dapsone, $200 \mathrm{mg}$ weekly, and in 1964 the dose had been decreased to $150 \mathrm{mg}$ weekly and in 1970 to $75 \mathrm{mg}$ weekly. In 1971 he had been suspected of having developed resistance to dapsone and his treatment had been changed to clofazimine, $100 \mathrm{mg}$ daily. From 1979 onwards he had been treated with combined therapy and he had been RFT in 1981. In 1986, at the age of 48, he developed erythematous lesions accompanied by sensory impairment on his left arm. A biopsy was taken and solid-stained AFB were seen, the BI was $5+$. He was diagnosed as a relapsed borderline lepromatous leprosy patient. MDT was commenced and the lesions soon resolved. After 2 years the treatment was once again discontinued.

Patient 2, a 30-year-old man, started MDT in 1986 for borderline-lepromatous leprosy. Since he suffered from a reversal reaction he was also treated with prednisone. His medication was discontinued in 1988. One month after he was RFT he developed a reversal reaction and prednisone was restarted. It was not possible in this patient to discontinue the prednisone, because each time the dose was tapered off the reaction flared-up. In April 1988, he also developed footdrop while still on prednisone treatment. 
At that time he was considered to have relapsed. Sections of biopsies with occasionally a solid-stained AFB confirmed this diagnosis and showed a BB/BL histopathology. He restarted $\mathrm{MDT}$ in addition to the steroid treatment and it was then possible to taper off the prednisone.

Patient 3 was 69 years old at the time of relapse. He had lived in Indonesia until 1936 and then emigrated to the Netherlands. In 1940 he had developed leprosy and had been diagnosed as having borderline-lepromatous leprosy. He had been treated with dapsone as soon as it became available in 1946 until 1964.

He was seen at the leprosy clinic again in 1985 because of sensory disturbances and ulcerations of the feet. He confided that he had been taking $100 \mathrm{mg}$ of dapsone twice a week since 1964. After a complete assessment no sign of activity was observed and he was advised to discontinue the treatment. One year later he had been without any complaints or signs of relapse. After a further 6 months, however, he developed disseminated erythematous macules and the diagnosis borderline-lepromatous leprosy was made and confirmed by biopsy. The BI was $5+$ and solid-stained AFB were seen in the biopsy. Upon MDT the lesions disappeared.

Patient 4, a 47-year-old man, was seen in 1986 at the leprosy clinic because of a paresis of the left foot. Shortly before, he had had an operation on this foot for osteomyelitis in the left hallux. He had been treated elsewhere from 1953 to 1966 for borderline-

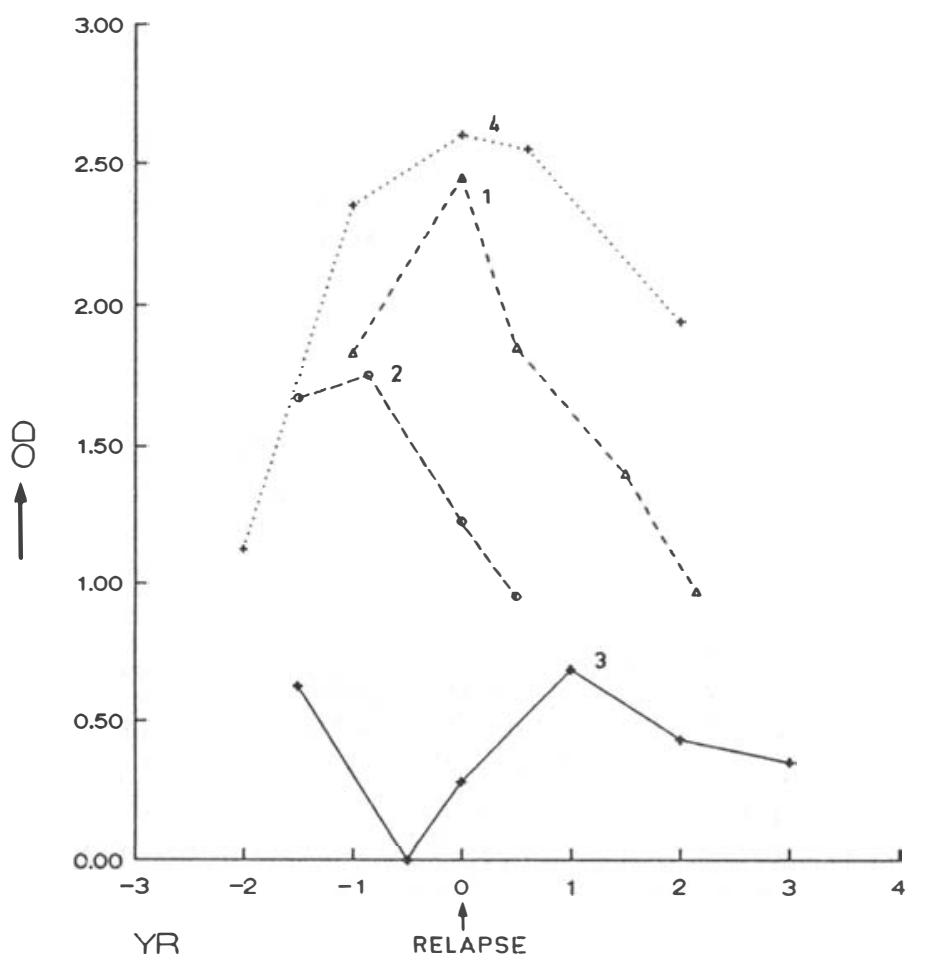

Figure 1. Levels of antibody in 4 multibacillary patients in whom a relapse was diagnosed. Numbers ref er to patients in text. 
tuberculoid leprosy. From 1970 to 1973 and from 1982 to 1984 he had taken dapsone, which had been prescribed by his general practitioner. He had been examined, and since there were no clinical signs of active leprosy, the treatment was discontinued. In 1988 he was admitted for an ulcer with cellulitis in the 3rd and 4th toe of the left foot. Since there was an increase in the PGL-I-ELISA-values skin smears were taken from his earlobes, and no acid-fast bacilli (AFB) could be observed. However, the upper arms and buttocks were positive for AFB and also solid-stained AFB were seen. At that time a biopsy was taken from a very faintly hypopigmented macule in which solid-stained AFB were also observed. He was diagnosed as having relapsed borderline-lepromatous leprosy and MDT was started.

The ELISA-values of these 4 patients with a proven relapse, were compared with the ELISA-values of multibacillary leprosy patients after RFT without an evident clinical relapse, from whom a number of serum samples were available. These patients were chosen at random.

\section{Results}

The results of the PGL-I ELISA in the 4 patients are shown in Figure 1. The levels of antibody against PGL-I in patients 1, 3 and 4 were increased before a clinical relapse was

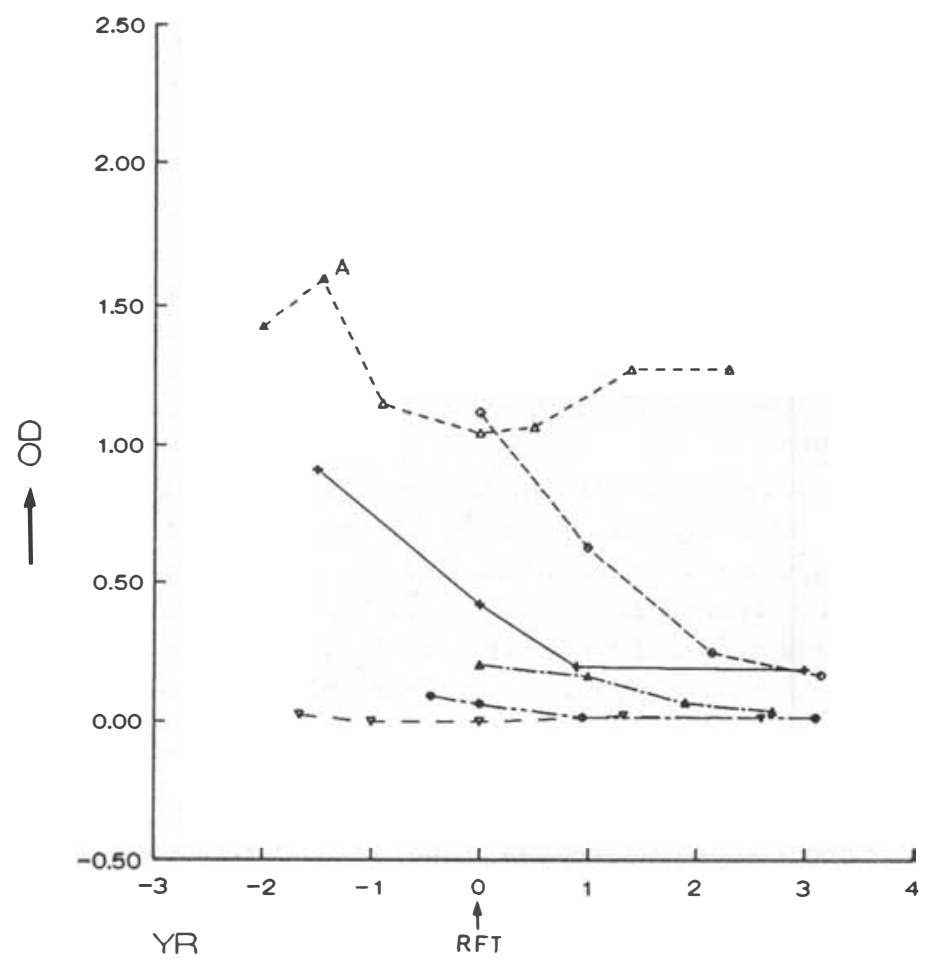

Figure 2. Levels of antibody in 6 multibacillary patients before and after release from treatment (RFT). Patient $\mathrm{A}$ is discussed in the text. 
diagnosed. In patient 2 the level of antibody was not increasing when the patient was clinically considered as relapsed, although two previous serum samples showed increased levels of antibody.

The outcome of the PGL-I ELISA in multibacillary leprosy patients who had not developed a clinical relapse and from whom consecutive serum samples were available was compared with the results of the relapsed patients (Figure 2). It can be seen that the levels of antibodies against phenolic glycolipid-I declined or showed persistently low levels after RFT in these 6 patients who showed no clinical signs of relapse. The sixth patient (A) showed increased levels.

\section{Discussion}

In patients 1, 2 and 3 the relapse was diagnosed clinically and confirmed by histopathology. In patient 4 there were no clinical signs of active leprosy. However, due to an increase in the ELISA values, a biopsy was taken and he was diagnosed as relapsed. All 4 patients were classified as multibacillary.

As shown in Figure 1 patient 1 still had a very high level of antibody-even 5 years after RFT. When the diagnosis of relapse (e.g. clinical and bacteriological reactivation of the disease) was made the level of antibody had risen further. After the start of MDT the levels of antibody declined rapidly and correlated to the observed clinical improvement. It is possible that at the moment the first serum sample was taken, 5 years after RFT, the patient was already in relapse but this was clinically undetectable.

The levels of antibody on patient 2 were not increased as expected. This could be explained on the basis that the prednisone therapy the patient had received, because of the reversal reaction, also suppressed the antibody response. The patient was treated with prednisone according to the generally held view that a reversal reaction shortly after RFT, could not be a relapse, but rather reflects an increase in cell-mediated immunity due to the discontinuation of dapsone. ${ }^{11.12}$ In this patient, however, the reversal reaction reflected a multiplication of bacilli. This multiplication was not followed by increased levels of antibody. Therefore, the patient had not received the necessary antimycobacterial therapy immediately.

The levels of antibody in patients 1 and 4, however, followed the expected pattern-a rise before clinical relapse and a decline after the initiation of treatment.

Figure 1 also shows a transient increase in levels of antibody just after the start of treatment in patient 3 . This could be due to the effective treatment and consequently a sudden release of antigens from dead or dying bacilli. ${ }^{1}$ A similar rise in levels of antibody after the start of treatment have been observed by Melsom et al. ${ }^{13}$ for lepromatous patients and by Dahle et al. ${ }^{14}$ for tuberculoid patients using a Radio Immuno-Assay (RIA) against Mycobacterium leprae antigen-7.

Figure 2 shows the levels of antibody in patients who did not relapse after RFT. One of the patients (A) showed a significant rise in the level of antibody 1.5 years after RFT. This patient had been diagnosed as having BL leprosy in 1984. He had been treated previously in Suriname for 10 years. MDT was started, but compliance of the treatment had been irregular. Nevertherless, he had been released from treatment in November 1987. Thereafter, he visited the outpatient department regularly. In August 1989, he observed an erythematous patch on his right cheek which could have been leprosy. A relapse was 
suspected, however, the smear was negative, and as the patch disappeared within a few weeks it was decided to wait. The levels of antibody did not fall below an OD of 1.0 after RFT and since the level of antibody has increased further at present, he may relapse.

Among the patients presented in Figure 2, he is the only patient in whom, at a certain moment, there were clinical signs for a suspected relapse.

The results presented in this paper show that in 3 out of 4 patients with an established relapse the levels of antibody to PGL-I increased. Of the 6 patients who did not relapse after RFT, 5 showed a decrease in the levels of antibody or remained consistently low. Contrary to what had been reported for paucibacillary patients ${ }^{6}$ in whom the levels of antibody to PGL-I had no indicative value for the diagnosis of a relapse, in multibacillary patients there seems to be a trend between the increased levels of antibody to PGL-I and a clinical relapse.

However, this trend must be confirmed in a larger group of patients in whom longitudinal serum samples are analysed before any definite conclusion concerning the predictive value of this test for relapses can be made.

\section{Acknowledgments}

We thank the Netherlands Leprosy Relief Association, the Associazione Italiana 'Amici di R. Follereau' and the Q.M. Gastmann Wichers Stichting for their financial support. Dr B. Tank is thanked for correcting the English.

\section{References}

1 WHO Technical Reports Series, 5th Report No. 607,24, 1977; referring 4th Report, No. 459, 1970.

2 Touw-Langendijk EJM, Naafs B. Relapses in leprosy after release from control. Lepr Rev, 1979; 50: $123-7$.

3 Pattyn SR, Ellard GA, Freeksen E, Grosset J, Huikeshoven H, Leiker DL, Noordeen SK, Seydel SK. Report of the sub-group on therapy. Health Cooperation Papers, 1983; 1: 187-9.

${ }^{4}$ Hastings RC. Release from treatment and follow-up. Health Cooperation Papers, 1983; 1: 77-9.

5 Naafs B. Leprosy reactions and their management, differential diagnosis with relapse. Health Cooperation Papers, 1983; 1: 73-6.

6 Naafs B, Lyons NF, Matemera BO. Serology to detect relapses after multiple drug treatment (MDT). Health Cooperation Papers, 1986; 7: 73-6.

7 Klatser PR, de Wit MYL, Fajardo TT, Cellona RV, Abalos RM, de la Cruz EC, Madarang MG, Hirsch DS, Douglas JT. Evaluation of Mycobacterium leprae antigens in the monitoring of a dapsone-based chemotherapy of previously untreated lepromatous patients in Cebu, Philippines. Lepr Rev, 1989; 60: 178-86.

8 Leiker DL. Management of leprosy in The Netherlands. Health Cooperation Papers, 1983; 1: 95-7.

9 Brett SJ, Payne SN, Gigg J, Burgess P, Gigg R. Use of synthetic glycoconjugates containing the Mycobacterium leprae specific and immunodominant epitope of phenolic glycolipid I in the serology of leprosy. Clin exp Imm, 1986; 64: 476-83.

${ }^{10}$ Klatser PR, Naafs B, Faber WR. Serologische diagnostiek van lepra. Ned Tijdschr Geneeskund, 1991; 135: 932-4.

11 Naafs B, Lyons NF, Madombi L, Matemera BO, Ellis BPB. Short term WHO advised multiple drug treatment of paucibacillary leprosy. Ind J Lepr, 1986; 58: 348-53.

12 Pannikar V, Jesudasan K, Vijayakumaran P, Christian M. Relapse or late reversal reaction. Int J Lepr, 1989; 57: $526-8$.

13 Melsom R, Harboe M, Naafs B. Class specific anti-Mycobacterium leprae antibody assay in lepromatous leprosy (BL-LL) patients during the first two to four years of DDS treatment. Int J Le pr, 1982; 50: 271-81.

14 Dahle JS, Warndorff-van Diepen T, Touw-Langendijk EJM, Belehu A. Effect of treatment on antibody activity against $M$. leprae antigen-7 in tuberculoid leprosy. Int $J$ Lepr, 1983; 51: 312-20. 
Suivi des patients souffrant de lepre multibacillaire au moyen de la methode ELISA sur un support de glycolipides phenoliques. L'augmentation des valeurs de la methode ELISA après l'arret du traitement est-elle indicative d'une recidive?

\author{
R A M Chin-A-Lien, W R Faber, M M van Rens, D L Leiker, B NaAfs \\ ET P R KLATSER
}

Résumé On espérait grâce à l'introduction des tests sérologiques reproductibles pouvoir dépister les récidives chez les lépreux après l'arrêt du traitement, avant la survenue de réactions néfastes et avant que les patients ne deviennent infectieux. On a examiné l'intérêt éventuel de la méthode ELISA en utilisant un analogue semisynthétique des glycolipides phénoliques-I pour dépister les anticorps dirigés contre cet antigène et qui permet de prédire une récidive chez les patients multibacillaires. Contrairement à ce qui avait été rapporté dans le cas des patients paucibacillaires, ce test a permis de dépister les récidives précoces chez les patients multibacillaires. Chez 3 patients multibacillaires sur 4 qui avaient récidivés, les valeurs obtenues avec la méthode ELISA avaient augmenté. Les valeurs inférieures obtenues avec la méthode ELISA chez un des patients qui avait récidivé pouvaient être attribuées à la corticothérapie. Chez les patients multibacillaires qui n'avaient pas récidivé après l'interruption du traitement, les valeurs obtenues avec la méthode ELISA étaient basses ou avaient baissés de manière consistante. Chez un seul patient seulement les valuers avaient augmenté suite à son interruption du traitement et sur le plan clinique, on soupçonnait une récidive.

\title{
Continuacion del estudio de pacientes leprosos multibacilares utilizando un ELISA basado en un glicolipido-I fenolico. Los valores crecientes de ELISA indican una recaida despues del tratamiento?
}

\author{
R A M Chin-A-Lien, W R Faber, M M van Rens, D L Leiker, B NaAfs y \\ P R KLATSER
}

\begin{abstract}
Resumen Después de la introducción de pruebas serológicas reproducibles, se esperaba que se podrían detectar recaídas en los pacientes leprosos, después de descontinuar el tratamiento, antes de que ocurriésen reacciones dañinas y antes de que los pacientes se pusieran infecciosos. Se investigó el valor que podría tener un ELISA utilizando un producto analógico semi-sintético de glicolipido-I fenólico para la detección de anticuerpos a este antígeno, para pronosticar una recaída en los pacientes multibacilares. En contraste con lo que se ha informado sobre los pacientes paucibacilares, esta prueba fue útil para detectar recaídas tempranas en los pacientes multibacilares. En 3 de los 4 pacientes multibacilares que recayeron, hubo un aumento en los valores de ELISA. La reducción de valor ELISA en el único paciente recaído se podia atribuir a la terapia corticoesteroide. En los pacientes multibacilares que no recayeron después de descontinuar el tratamiento (RFT), los valores de ELISA erán bajos o decrecieron de una forma constante. En solamente un paciente hubo un aumento de ELISA después de descontinuar el tratamiento, y se sospechó por razones clínicas que desarrollaba una recaída.
\end{abstract}

